\title{
PENGARUH CORPORATE SOCIAL RESPONSIBILITY TERHADAP NILAI PERUSAHAAN DENGAN UKURAN PERUSAHAAN DAN PROFITABILITAS SEBAGAI VARIABEL MODERASI PADA PERUSAHAAN FARMASI YANG TERDAFTAR DI BURSA EFEK INDONESIA
}

\author{
NI LUH LAKSMI RAHMANTARI
}

\author{
Universitas Tabanan \\ e-mail: rahmantarilaksmi95@gmail.com
}

\begin{abstract}
ABSTRAK
Penelitian ini bertujuan untuk (1) menganalisis pengaruh Corporate Sosial Responsibility terhadap nilai perusahaan, (2) menganalisis ukuran perusahaan terhadap nilai perusahaan pada, (3) menganalisis profitabilitas terhadap nilai perusahaan, (4) menganalisis ukuran perusahaan dalam memoderasi hubungan antara Corporate Sosial Responsibility terhadap nilai perusahaan (5) menganalisis profitabilitas dalam memoderasi hubungan antara Corporate Sosial Responsibility terhadap nilai perusahaan. Nilai perusahaan dipengaruhi oleh Corporate Sosial Responsibility, ukuran perusahaan dan profitabilitas. Penelitian ini menggunakan Analysis Moderated Regresion dengan SPSS for Windows 25.0. Sampel dalam penelitian ini menggunakan delapan perusahaan farmasi yang terdaftar di Bursa Efek Indonesia. Menggunakan laporan tahunan (annual report) dengan rentang waktu 2014-2017. Hasi penelitian yang diperoleh adalah (1) Corporate Social Responsibility berpengaruh positif signifikan terhadap nilai perusahaan, (2) Ukuran perusahaan berpengaruh positif signifikan terhadap nilai perusahaan, (3) Profitabilitas berpengaruh negatif signifikan terhadap nilai perusahaan, (4) Ukuran perusahaan tidak mampu memoderasi hubungan antara Corporate Social Responsibility (CSR) dan nilai perusahaan, (5) Profitabilitas tidak mampu memoderasi hubungan antara Corporate Social Responsibility (CSR) dan nilai perusahaan. Temuan penelitian ini diharapkan mampu memberikan pemahaman bahwa perusahaan lebih terbuka terhadap informasi tanggung jawab sosial dan lingkungan dengan pengukuran yang lebih update dan didasarkan pada GRI 4. Kemudian perusahaan perlu juga melihat dari teknis fundamental artinya lebih melihat kembali pada sisi jangka panjang dan tidak hanya melihat dari sisi jangka pendek dalam meningkatkan nilai perusahaan.
\end{abstract}

Kata kunci : Corporate Social Responsibility, Tobins'Q, ukuran perusahaan, profitabilitas, Return On Asset (ROA).

\begin{abstract}
This study aims to (1) analyze the effect of Corporate Social Responsibility on firm value, (2) analyze company size on firm value, (3) analyze profitability on firm value, (4) analyze company size in moderating the relationship between Corporate Social Responsibility towards Firm value (5) analyzes profitability in moderating the relationship between Corporate Social Responsibility and firm value. Firm value is influenced by Corporate Social Responsibility, company size, and profitability. This study uses Analysis Moderated Regression with SPSS for Windows 25.0. The sample in this study used eight pharmaceutical companies listed on the Indonesia Stock Exchange. Using the annual report (annual report) with a span of 2014-2017. The results of the research obtained are (1) Corporate Social Responsibility has a significant positive effect on firm value, (2) Firm size has a significant positive effect on firm value, (3) Profitability has a significant negative effect on firm value, (4) Firm size is unable to moderate the relationship. between Corporate Social Responsibility (CSR) and company value, (5) Profitability is not able to moderate the relationship between Corporate Social Responsibility (CSR) and firm value. The findings of this study are expected to be able to provide an understanding that companies are more open to social and environmental responsibility information with more updated measurements and are based on GRI 4. Then companies need to also look at technical fundamentals, meaning that they look more at the long-term side and not only the short-term side in increasing company value.
\end{abstract}

Keywords: Corporate Social Responsibility, Tobins'Q, company size, profitability, Return On Asset (ROA). 


\section{PENDAHULUAN}

Nilai perusahaan adalah hal terpenting yang wajib diperoleh perusahaan dengan maksimal. Penilian yang maksimal dari suatu perusahaan dilihat dari kemampuan bertahan dalam keberlangsungan hidup perusahaan, maka nilai perusahaan dapat tetap terjaga dengan baik (Rumajar, 2018). Menurut Ananda, dkk (2016) menyatakan bahwa nilai perusahaan adalah nilai pasar atau yang berhubungan dengan harga saham, surat berharga, modal dan hutang dalam perusahaan yang beredar. Artinya nilai perusahaan merupakan penilaian secara keseluruhan dalam perusahaan yang berkaitan dengan persepsi investor yang berhubungan dengan harga saham yang beredar, ekuitas, dan laba yang diperoleh perusahaan. Nilai perusahaan meningkat apabila perusahaan mampu memaksimakan kesejahteraan dan kemakmuran pemegang saham (Rumajar, 2018). Oleh karena itu, dalam melakukan peningkatan justru membutuhkan informasi tambahan yang dapat menggugah dan menarik minat stakeholder serta dapat memberikan kesan positif bagi pihak eksternal perusahaan terutama masyarakat salah satunya terkait dengan informasi tanggungjawab sosial dan lingkungan atau disebut dengan Corporate Social Responsibility (CSR)

Nilai perusahan berhubungan laba dan peningkatan harga saham, serta naik turunnya kondisi pangsa pasar yang secara otomatis berkaitan dengan laju pertumbuhan dan nilai perusahaan. Salah satunya yang dapat dilihat adalah perusahaan farmasi. Perusahaan farmasi adaah perusahaan yang sangat yang bergerak daam bidang penunjang kesehatan. Namun, perusahaan farmasi mengalami penurunan harga saham misalnya Kalbe Farma Tbk pada tahun 2016 mengalami kenaikan sebesar Rp1.515 dan menurun pada tahun 2017 sebesar Rp1.380. Selain itu, Kimia Farma (Persero) Tbk mengalami kenaikan pada tahun 2016 sebesar Rp 2.750 dan mengalami penurunan pada tahun 2017 sebesar Rp 2.550. Hal serupa terjadi pada Merck Tbk dan Tempo Scan Pacific Tbk mengalami penurunan pada tahun 2017 sebesar Rp 5.700 dan Rp 1.405. Akibatnya terjadi laju pertumbuhan yang lambat dalam perusahaan farmasi dimana Analisa Perkembangan Industri Edisi II-2018 oleh Kementerian Perindustrian Republik Indonesia bahwa pada tahun 2015-2016 selalu mencatat pertumbuhan tertinggi, namun pada triwulan IV tahun 2017 terjadi penurunan sebesar 5,46\% hingga mengalami kontraksi penurunan sebesar $6,30 \%$ pada triwulan I tahun 2018. Sehingga, dibutuhkan optimalisasi dalam menegakkan penilaian perusahaan, maka dibutuhkan tambahan informasi terkait dengan tanggungjawab sosial perusahaan yaitu Corporate Social Responsibility.

Teori yang berkaitan dengan CSR adalah teori stakeholder dimana teori ini menyatakan bahwa perusahaan tidak akan terlepas dari masalah, isu dan fenomena terhadap sosial dan lingkungan. Maka dari itu perusahaan perlu menjaga legitimasi perusahaan demi tercapainya tujuan perusahaan dan stabilitas perusahaan (Ardianto dan Machfudz, 2011:75-76). Terarney (2000) dalam Putra (2013) menyatakan CSR dapat membantu dalam meningkatkan nilai perusahaan dengan mengurangi asimetri informasi keuangan dan non keuangan. Hubungan CSR terhadap nilai perusahaaan ini merujuk pada penelitian Susanti, et al. (2012); Wulandari (2015); Harjoto dan Laksmana (2016); Humairoh (2017); Marius dan Masri (2017). Yang menyatakan bahwa CSR berpengaruh positif terhadap nilai perusahaan. Hal ini disebablan karena penerapan CSR yang dilakukan perusahaan akan membantu perushaaan dalam memperhatikan tiga aspek terpenting yang wajib perusahaan aplikasikan yaitu aspek sosial, ekonomi dan lingkungan. Untuk mengetahui hubungan keduanya maka dibutuhkanlah peran moderasi tentunya berkaitan dengan faktor-faktor nilai perusahaan yaitu ukuran perusahaan dan profitabilitas sebagai suatu bagian bahwa variabel ini dapat meingkatkan hubungan keduanya

Corporate Social Responsibility adalah suatu konsep pertanggungjawaban perusahaan berkomitmen untuk berkontribusi dalam pengembangan ekonomi berkelanjutan melihat pada keseimbangan terhadap aspek sosial, ekonomis dan lingkungan (Untung, 2009;1). Corporate Social Responsibility merupakan hal yang wajib dilaksanakan sesuai dengan Undang-Undang Nomor 40 tahun 2007. Namun, Widokarti (2014) menyatakan bahwa masalah mendasar yang terjadi terkait penyaluran dan pengelolaan dana CSR di Indonesia, yakni mengenai kejelasan bagaimana sebuah perusahaan seharusnya mengimplementasikan program CSR-nya. Hayunta, dkk (2013) menyatakan terkait CSR dari tahun 2009 hingga 2011. Tahun 2011, sebanyak 16 perusahaan rata-rata alokasi jumlah dana CSR adalah 1,6 persen dari keuntungan perusahaan, untuk perusahaan BUMN alokasi rata-rata adalah 2,7 persen dari keuntungan, serta untuk perusahaan swasta adalah 0,53 persen dari keuntungan. Maka dari itu dibutuhkan peran moderasi untuk dapat memperkuat hubungan CSR dengan nilai perusahaan yaitu ukuran perusahan dan profitabilitas.

Ukuran perusahaan merupakan besar kecilnya perusahaan dengan memperhatikan total aktiva keseluruhan sebagai cerminan perkembangan kekayaaan perusahaan sesuai dengan aktivitas perusahaan. Dengan begitu dapat meyakinkan investor bahwa besar perusahaan akan memberikan kemudahan dalam pengembalian tingkat investasi, maka secara otomatis nilai perusahaan akan meningkat. Pernyataan ini didukung oleh Pratama dan Wiksuana (2016); Meizari dan Oktaviani (2017); Andawasatya et al. (2017); Hamyat, et al. (2017); Sofia dan Akhmadi (2018). Andawasatya et al. (2017) dan Hamyat et al.(2017) 
menyatakan bahwa ukuran perusahaan berpengaruh positif terhadap nilai perusahaan hal ini disebabkan karena perusahaan besar mampu masuk dengan mudah ke pasar modal dan dengan mudah memperoleh dana untuk keberlangsungan hidup perusahaan. Sehingga, ukuran perusahaan mampu menguatkan hubungan CSR terhadap nilai perusahaan karena perusahaan besar menerapkan berbagai macam aktivitas yang berkaitan dengan CSR yang tidak hanya untuk external perusahaan tetapi untuk internal perusahaan.

Ukuran perusahaan mampu memoderasi hubungan CSR dengan nilai perusahaan disebabkan karena perusahaan memberikan kesempatan untuk dapat berkembang dalam aspek yang perlu diperhatikan dalam kesejahteraan masyarakat yang tidak hanya untuk kepentingan perusahaan semata. Ukuran perusahaan ini didukung oleh pernyataan dari Pratama dan Wiksuana (2016); Meizari dan Oktaviani (2017); Andawasatya et al. (2017); Hamyat,et al. (2017); Sofia dan Akhmadi (2018).Ukuran perusahaan yang diperhitungkan dengan total aktiva dimiliki perusahaan ini meliputi besar kecilnya perusahaan yang sekaligus berimbas pada luasnya pengungkapan CSR yang diakibatkan oleh aktivitas perusahaan yang banyak inilah untuk dapat meningkatkan nilai perusahaan maka dibutuhkanlah CSR tersebut.

Ukuran perusahaan adalah besar kecilnya total aktiva suatu perusahaan karena total aktiva merupakan cerminan kekayaan perusahaan (Goh and Simanjuntak (2017)). Pratama dan Wiksuana (2016) menyatakan bahwa semakin besar perusahaan maka akan mempengaruhi dalam penentuan pendanaan agar mampu mengoptimalkan nilai perusahaan. Berdasarkan Signaling Theory yang dinyatakan oleh Battacharya (1979) (dalam Sofia dan Akhmadi, 2018) bahwa perusahaan besar dengan mudah mengakses ke pasar modal maka dengan mudah pula mendapatkan dana yang lebih besar. Sehingga, mampu memperoleh sinyal positif dari investor. Putri, dkk (2016) dan Puspaningrum (2017) menunjukkan hasil bahwa ukuran perusahaan mampu memoderasi hubungan Corporate Social Responsibility terhadap nilai perusahaan diartikan bahwa perusahaan besar akan mengungkapkan informasi yang berkaitan dengan aspek sosial, ekonomi dan lingkungan lebih banyak disebabkan karena perusahaan besar cenderung melakukan aktivitas banyak yang cenderung menarik minat investor dalam berinvestasi. Selain ukuran perusahaan faktor yang yang dapat meningkat dan memperkuat hubungan CSR dengan nilai perusahaan adalah profitabilitas

Menurut Utari, dkk $(2014 ; 63)$ menyatakan bahwa profitabilitas merupakan kemampuan dari manajemen perusahaan dalam mendapatkan laba. Dalam Signaling Theory yang dinyatakan oleh Battacharya (1979) (dalam Sofia dan Akhmadi, 2018) bahwa profitabilitas yang tinggi akan memberikan respon baik dari investor karena dapat meningkatkan harga saham dan meningkatkan nilai perusahaan. Humairoh (2017), Ramadhani (2017) dan Karundeng, dkk (2018) yang menyatakan profitabilitas mampu memoderasi hubungan CSR dengan nilai perusahaan. Karena sebagian dari keuntungan perusahaan terserap untuk kepentingan program berkaitan dnegan tanggungjawab sosial perusahaan. Terserapnya keuntungan yang diperoleh perusahaan ini dapat menjaga kelangsung hidup perusahaan berdasarkan operasionalnya.

Meningkatnya profitabilitas menimbulkan kondisi perusahaan yang berada pada level meningkat sehingga pertumbuhan perusahaan akan terbantu dan dapat menarik minat investor dalam melakukan investasi karena profitabilitas akan memberikan sinyaposotif bagi investor lewat permintaan saham. Hal ini mendukung penelitian dari Li-Ju Chen dan Shun-Yu Chen (2011); Denziana dan Monica (2016); Sucuahi dan Cambarihan (2016); Pratama dan Wiksuana (2016); Karundeng, dkk. (2018).

Profitabilitas dapat meningkatkan CSR karena sebagian keuntungan perusahaan ditujukan untuk melakukan program CSR sebagai kewajiban perusahaan untuk dapat meningkatkan nilai perusahaan. Pernyataan ini didukung oleh penelitian Ekatah et al.(2011); Wulandari (2015); Nawaiseh et al. (2015); Humairoh (2017); Karundeng,dkk. (2018). Perusahaan dengan tingkat profitabilitas baik mampu meberikan kestabilan dalam melakukan program CSR karena program CSR membutuhkan dana yang tentunya berasal dari serapan keuntungan perusahaan sehingga mampu meningkatkan nilai perusahaan

Oleh karena itu, penulis tertarik mengangkat judul Pengaruh Corporate Social Responsibility terhadap Nilai Perusahaan dengan Ukuran Perusahaan dan Profitabilitas sebagai Variabel Moderasi pada Perusahaan Farmasi yang terdaftar di Bursa Efek Indonesia.

\section{Rumusan Masalah}

Adapun rumusan masalah dalam penelitian ini sebagai berikut:

1. Bagaimana pengaruh Corporate Social Responsibility terhadap Nilai Perusahaan pada Perusahaan Farmasi yang terdaftar di Bursa Efek Indonesia.

2. Bagaimana pengaruh Ukuran perusahaan terhadap Nilai Perusahaan pada Perusahaan Farmasi yang terdaftar di Bursa Efek Indonesia.

3. Bagaiman pengaruh Profitabilitas terhadap Nilai Perusahaan pada Perusahaan Farmasi yang terdaftar di Bursa Efek Indonesia.

4. Bagaimana Ukuran perusahaan memoderasi hubungan Corporate Social Responsibility terhadap Nilai Perusahaan pada Perusahaan Farmasi yang terdaftar di Bursa Efek Indonesia. 
5. Bagaimana Profitabilitas memoderasi hubungan Corporate Social Responsibility terhadap Nilai Perusahaan pada Perusahaan Farmasi yang terdaftar di Bursa Efek Indonesia.

\section{Tujuan Penelitian}

Adapun rumusan masalah dalam penelitian ini sebagai berikut:

1. Bagaimana pengaruh Corporate Social Responsibility terhadap Nilai Perusahaan pada Perusahaan Farmasi yang terdaftar di Bursa Efek Indonesia.

2. Bagaimana pengaruh Ukuran perusahaan terhadap Nilai Perusahaan pada Perusahaan Farmasi yang terdaftar di Bursa Efek Indonesia.

3. Bagaiman pengaruh Profitabilitas terhadap Nilai Perusahaan pada Perusahaan Farmasi yang terdaftar di Bursa Efek Indonesia.

4. Bagaimana Ukuran perusahaan memoderasi hubungan Corporate Social Responsibility terhadap Nilai Perusahaan pada Perusahaan Farmasi yang terdaftar di Bursa Efek Indonesia.

5. Bagaimana Profitabilitas memoderasi hubungan Corporate Social Responsibility terhadap Nilai Perusahaan pada Perusahaan Farmasi yang terdaftar di Bursa Efek Indonesia.

\section{METODELOGI PENELITIAN}

Penelitian ini menggunakan metode kuantitatif dimana mempergunakan data time series atau masa lampau terkait dengan Laporan Tahunan Perusahaan Farmasi yang terdaftar di Bursa Efek Indonesia. Dengan periode atau rentang waktu aporan Tahunan adalah 2014-2017 yang dapat di akses dalam www.idx.com. Variabel dalam peneitian ini terdiri dari Corporate Social Responsibility (X1), Ukuran perusahaan (X2), Profitabilitas (X3), dan Nilai Perusahaan (Y).

\section{Definisi Operasional}

1) Nilai perusahaan

Menurut Waluyo (2017) rumus nilai perusahaan diukur dengan Tobin's $Q$ dapat dirumuskan sebagai berikut.

$$
\mathrm{Q}=\frac{\text { MVS }+\mathrm{D}}{\mathrm{BVE}+\mathrm{D}}
$$

Keterangan :

$$
\begin{array}{ll}
\text { Q } & =\text { Nilai Perusahaan } \\
\text { MVS } & =\text { Nilai pasar saham } \\
\text { BVE } & =\text { Book Value Equity } \\
\text { D } & =\text { Debt atau Nilai Buku dari Total Utang }
\end{array}
$$

2) Corporate Social Responsibility

Pengungkapan CSR disesuaikan dengan kategori G4-Global Reporting Initiative (GRI) yaitu 91 pengungkapan item Corporate Social Responsibility (CSR). Yang dapat diakses dengan www.globalreporting.org. Menurut Wulandari (2015) CSR dengan perhitungan sebagai berikut.

$$
\mathrm{CSRIj}=\frac{\sum x i j}{n j}
$$

Keterangan :

$$
\begin{array}{ll}
\mathrm{CSRIj} & =\text { Pengungkapan Corporate Social Responsibility Index perusahaan } \mathrm{j} \\
\mathrm{Nj} & =\text { Jumlah item untuk perusahaan } \mathrm{j}, \\
\mathrm{nj} & =91 \\
\mathrm{Xij} & =1 \text { jika item } \mathrm{i} \text { diungkapkan, } 0=\text { jika item i tidak diungkapkan }
\end{array}
$$

3) Ukuran Perusahaan

Pengukurannya menggunakan total asset atau total aktiva. Menurut Jekwam dan Hermuningsih (2018) dengan rasio sebagai berikut.

Size $=\ln ($ total asset $)$

4) Profitabilitas

Profitabilitas merupakan besarnya perolehan keuntungan yang dihitung dan dihasilkan oleh kegiatan perusahan lewat kinerja keuangan selama periode akuntansi. Menurut Nugroho (2012) profitabilitas diukur dengan mempergunakan ROA adalah sebagai berikut. 


$$
\begin{array}{ll} 
& \text { ROA }=\frac{\text { NIAT }}{T A} \\
\text { NIAT } & =\text { Net Income After Tax (pendapatan bersih setelah pajak) } \\
\text { TA } & =\text { Total Asset }
\end{array}
$$

\section{Populasi dan Sampel}

Menurut Dharmanegara, dkk (2016) populasi target merupakan populasi yang telah ditentukan sesuai dengan masalah penelitian sebelum penelitian dilakukan. Populasi target pada penelitian ini adalah perusahaan farmasi yang go public di Bursa Efek Indonesia dengan periode 2014 - 2017. Penelitian ini menggunakan sampel akses mengacu pada penelitian Dharmanegara, dkk (2016). Penelitian ini menggunakan sampel akses dengan syarat yang cukup mudah karena data yang diperoleh melalui website dan apabila tidak dapat diakses data tersebut tidak dapat dipergunakan. Terdapat delapan perusahaan farmasi yang dijadikan sampel dalam penelitian ini.

\section{Teknis Analisis Data}

Teknis analisis data dalam penelitian ini menggunakan Moderated Regresion Analysis. Sebelumnya dilakukan pengujian asumsi klasik untuk memenuhi syarat Moderated Regresion Analysis.

1. Uji Asumsi Klasik

a. Uji Normalitas

Pengujian ini menggunakan analisis statistik dengan Kolmogorov-Smirnov Z (1-Sample K-S) (Ghozali, 2016:30). Jika pengujian menghasilkan nilai signifikansi lebih besar dari 0,05 atau $\alpha>0,05$ maka asumsi normalitas terpenuhi.

b. Uji Autokorelasi

Pengujian autokorelasi dengan menggunakan Durbin-Watson Test. Asumsi non-autokorelasi terpenuhi jika pengujian menghasilkan nilai $\mathrm{du}<\mathrm{dw}<4-\mathrm{du}$. (Ghozali, 2016:108).

c. Uji Multikoleniaritas

Pengujian ini dilakukan dengan menghitung nilai VIF (Variance Inflating Factor). Jika pengujian menghasilkan nilai VIF lebih kecil dari 10 atau $\alpha<10$ maka asumsi non-multikolinearitas terpenuhi (Ghozali, 2016:103).

d. Uji Heterokedastisitas

Prinsip metode ini adalah dilihat dari segi pola residual $\left(\mathrm{ui}^{2}\right)$ terhadap Yi hasil taksiran. Melalui pembentukan pola sebaran tersebut memperlihatkan pola yang sistematis (plot berhubungan teratur) berarti terjadi heteroskedastis.

2. Analisis Moderasi

Pengujian ini dilakukan dengan uji residual yaitu untuk menguji pengaruh deviasi (penyimpangan) dari suatu model fokusnya adalah ketidak cocokkan (lack of fit) yang dihasilkan dari deviasi hubungan linier antar variabel independen (Ghozali, 2016:228).

a. Moderasi Model 1

Ukuran perusahaan sebagai pemoderasi antara Corporate Social Responsibility dengan nilai perusahaan.

b. Moderasi Model 2

$$
\text { Model } 1:\left|e_{1}\right|=\beta o+\beta_{1} Y
$$

Profitabilitas sebagai pemoderasi antara Corporate Social Responsibility dengan nilai perusahaan.

$$
\text { Model } 2:|\mathrm{e} 2|=\beta \mathrm{o}+\beta 2 \mathrm{Y}
$$

Hal ini dijelaskan dengan syarat koefisien $\beta 1$ nilai perusahaan (Y) signifikan dan negatif (Ghozali, 2016:2018).

\section{Hipotesis Penelitian}

H1 : Corporate Social Responsibility berpengaruh positif signifikan terhadap Nilai Perusahaan pada Perusahaan Farmasi yang terdaftar di Bursa Efek Indonesia.

H2 : Ukuran perusahaan berpengaruh positif signifikan terhadap Nilai Perusahaan pada Perusahaan Farmasi yang terdaftar di Bursa Efek Indonesia.

H3 : Profitabilitas berpengaruh positif signifikan terhadap Nilai Perusahaan pada Perusahaan Farmasi yang terdaftar di Bursa Efek Indonesia.

H4 : Ukuran perusahaan memoderasi hubungan Corporate Social Responsibility terhadap Nilai Perusahaan pada Perusahaan Farmasi yang terdaftar di Bursa Efek Indonesia.

H5 : Profitabilitas memoderasi hubungan Corporate Social Responsibility terhadap Nilai Perusahaan pada Perusahaan Farmasi yang terdaftar di Bursa Efek Indonesia. 


\section{HASIL DAN PEMBAHASAN}

\section{Uji Asumsi Klasik Model 1}

Uji asumsi klasik model 1 untuk menyandingkan CSR dengan Ukuran perusahaan terhadap nilai perusahaan. Sebelumnya persamaan regresi dilakukan dengan menjadikannya Log untuk memperkecil deviasi atau bias. Dengan persamaan regresi sebagai berikut.

$L Y_{1}=b o+b_{1} L X_{1}+b_{2} L X_{2}+b_{3} L X_{1} \cdot L X_{2}$

a. Uji Normalitas Model 1

Nilai residual Z1 dan Z2 sebesar 1.208 dan 0,108 dan memiliki signifikansi diatas level 0,05 sehingga model terdistribusi secara normal.

b. Uji Autokorelasi Model 1

Model 1 nilai $\mathrm{dL}$ tabel ( pada $\mathrm{n}=32$ dan variabel independen $\mathrm{k}=3$ ) adalah 1,244 dan dU tabel adalah 1,650 sedangkan nilai dw hasil hitung adalah 1,571. Sehingga terletak pada kriteria dua yaitu $\mathrm{dL}<$ $\mathrm{dW}<\mathrm{dU}$ atau tidak ada kesimpulan.

c. Uji Mutikoleniaritas Model 1

Seluruh variabel mengandung multikol karena variabel independen VIF > 10, hal ini merupakan suatu yang biasa terjadi pada kasus persamaan yang mengandung interaksi (Ghozali, 2016:107).

d. Uji Heterokedastisitas Model 1

Model hasil estimasi menunjukkan bahwa model 2 membentuk sebaran yang tidak beraturan antara regression studentized deleted residual dengan regression standardized predictive value, berarti tidak mengandung heteroskedastis.

\section{Analisis Regresi Model 1}

Analisis model 1 ini akan menggambarkan terkait interaksi yang terjadi antara CSR (X1) yang disandingkan dengan ukuran perusahaan (X2) terhadap nilai perusahaan (Y). Dengan hasil bahwa CSR berpengaruh negatif signifikan terhadap nilai perusahaaan dengan koefisien regresi sebesar 80,630 dengan signifikansi 0,003 . Ukuran perusahaan berpengaruh positif signifikan terhadap nilai perusahaan koefisien sebesar 32,352 tingkat signifikansi 0,05. Interaksi CSR dan ukuran perusahaan terhadap nilai perusahaan adalah sebesar sebesar 59,215 dan tingkat signifikansi lebih kecil dari 0,05. Hasil ini ditunjukan dalam tabel 1 adalah sebagai berikut.

Tabel 1. Analisis Regresi Model 1 Coefficients $^{\mathrm{a}}$

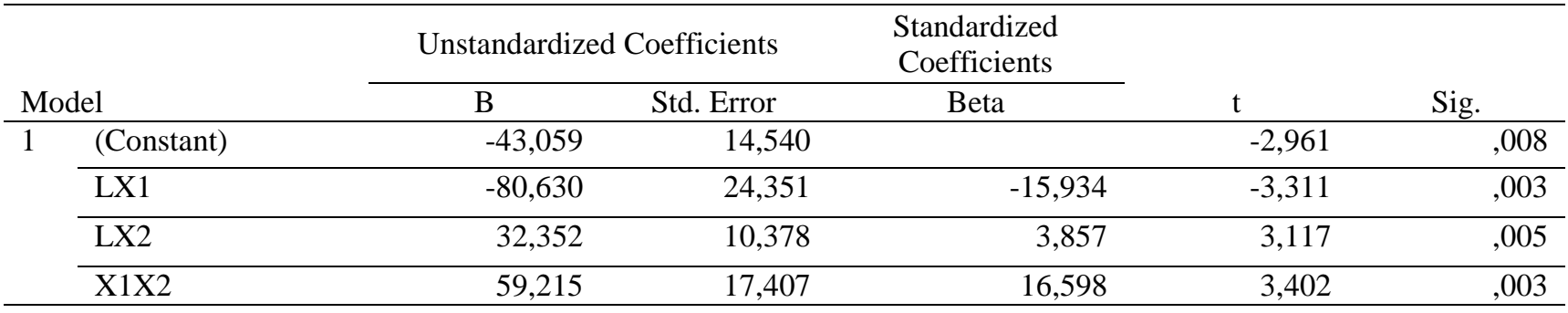

\section{Analisis Moderasi Model 1}

Analisis moderasi Model 1 menunjukkan bahwa nilai koefisien regresi $\beta 1$ nilai perusahaan (LY) terhadap nilai absolute e1 |e1| adalah positif sebesar 0,219 dan signifikan pada level 0,05 dengan nilai T hitung sebesar 2,318 dan nilai Sig sebesar 0,030 lebih kecil dari p value yaitu sebesar 0,05. Artinya bahwa variabel ukuran perusahaan (X2) bukan merupakan moderasi antara Corporate Social Responsibility (X1) dengan nilai perusahaan (Y). Syarat moderasi adaah negatif signifikan. Moderasi model 1 menggunakan uji residual yang ditunjukan pada tabel 2 sebagai berikut.

Tabel 2. Analisis Moderasi Model 1

\begin{tabular}{|c|c|c|c|c|c|c|c|c|c|c|c|}
\hline \multicolumn{12}{|c|}{ Coefficients $^{\mathrm{a}}$} \\
\hline \multirow[t]{2}{*}{ Model } & \multicolumn{2}{|c|}{$\begin{array}{c}\text { Unstandardized } \\
\text { Coefficients }\end{array}$} & \multirow{2}{*}{$\begin{array}{c}\begin{array}{c}\text { Standardized } \\
\text { Coefficients }\end{array} \\
\text { Beta }\end{array}$} & \multirow[t]{2}{*}{$\mathrm{t}$} & \multirow[t]{2}{*}{ Sig. } & \multicolumn{2}{|c|}{$\begin{array}{c}95,0 \% \\
\text { Confidence } \\
\text { Interval for B }\end{array}$} & \multicolumn{2}{|c|}{ Correlations } & \multicolumn{2}{|c|}{$\begin{array}{l}\text { Collinearity } \\
\text { Statistics }\end{array}$} \\
\hline & B & $\begin{array}{l}\text { Std. } \\
\text { Error }\end{array}$ & & & & $\begin{array}{l}\text { Lower } \\
\text { Bound }\end{array}$ & $\begin{array}{l}\text { Upper } \\
\text { Bound }\end{array}$ & $\begin{array}{l}\text { Zero- } \\
\text { order }\end{array}$ & Part & Tolerance & VIF \\
\hline (Constant) & ,043 &, 101 & & ,428 & ,673 &,- 167 & 253 & & & & \\
\hline LY & 219 & ,094 & ,443 & 2,318 & 030 & ,023 & 415 & ,443 & ,443 & 1,000 & 1,000 \\
\hline
\end{tabular}




\section{Uji Asumsi Klasik Model 2}

Uji asumsi klasik model 2 untuk menyandingkan CSR dengan profitabilitas terhadap nilai perusahaan. Sebelumnya persamaan regresi dilakukan dengan menjadikannya Log untuk memperkecil deviasi atau bias. Dengan persamaan regresi sebagai berikut.

$\mathrm{LY}_{1}=\mathrm{bo}+\mathrm{b}_{1} \mathrm{LX}_{1}+\mathrm{b}_{3} \mathrm{LX}_{3}+\mathrm{b}_{4} \mathrm{LX}_{1} \cdot \mathrm{LX}_{3}$.

a. Uji Normalitas Model 2

Nilai residual model 2 memiliki nilai Z1 dan Z3 sebesar 0,697 dan 0,717 dan memiliki signifikan diatas level 0,05 sehingga model terdistribusi secara normal.

b. Uji Autokorelasi Model 2

Nilai dL dalam model 2 ( pada $\mathrm{n}=32$ dan variabel independen $\mathrm{k}=3$ ) adalah 1,244 dan $\mathrm{dU}$ tabel adalah 1,650 sedangkan nilai dW hasil hitung adalah 1,802 . Sehingga terletak pada kriteria 3 yaitu $\mathrm{dU}<\mathrm{dW}$ $<4$ - dU atau tidak ada mengandung autokorelasi.

c. Uji Multikoleniaritas Model 2

Variabel LX3 dan X1X3 mengandung multikol karena nilai variabel independen VIF > 10, hal ini merupakan suatu yang biasa terjadi pada kasus persamaan yang mengandung interaksi (Ghozali, 2016: 104).

d. Uji Heterokedastisitas Model 2

Model 2 hasil estimasi menunjukkan bentuk sebaran yang tidak beraturan antara regression studentized deleted residual dengan regression standardized predictive value, berarti tidak mengandung heteroskedastis.

\section{Analisis Regresi Model 2}

Analisis model 2 ini akan menggambarkan terkait interaksi yang terjadi antara CSR (X1) yang disandingkan profitabilitas (X3) terhadap nilai perusahaan (Y). Dengan hasil bahwa CSR berpengaruh positif signifikan terhadap nilai perusahaaan dengan koefisien regresi sebesar dengan 5,519 terhadap nilai perusahaan tingkat signifikansi sebesar 0,004 lebih kecil dari 0,05. Profitabilitas berpengaruh positif signifikan terhadap nilai perusahaan koefisien sebesar negatif sebesar 3,845 terhadap nilai perusahaan dan hubungan tersebut signifikansinya sebesar 0,029 lebih kecil dari 0,05. Interaksi CSR dan profitabilitas sebesar -7,194 dan signifikan pada level 0,05 terhadap nilai perusahaan Hasil ini ditunjukan dalam tabel 3 adalah sebagai berikut.

Tabel 3. Analisis Regresi Model 2

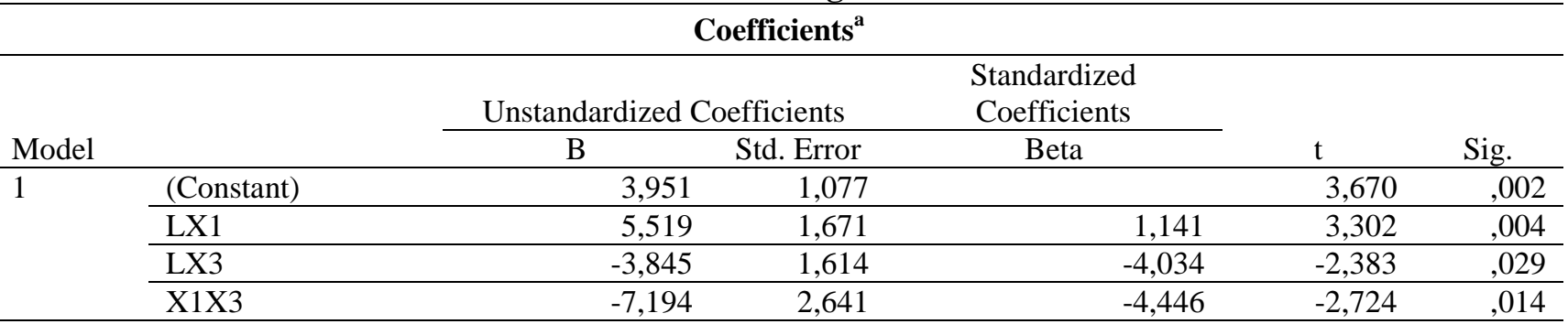

\section{Analisis Moderasi Model 2}

Analisis moderasi Model 2 menunjukkan bahwa nilai koefisien regresi untuk pengaruh nilai perusahaan terhadap nilai absolute e2 |e2| adalah positif 0,164 dan tidak signifikan pada level 0,05 dengan nilai T hitung sebesar 2,004 dengan nilai Sig sebesar 0,060 lebih besar dari p value yaitu sebesar 0,05. Artinya bahwa variabel profitabilitas (X3) bukan merupakan moderasi antara Corporate Social Responsibility (X1) dengan nilai perusahaan (Y). Analisis moderasi model 2 ditunjukan pada tabel 4 adalah sebagai berikut.

Tabel 4. Analisis Moderasi Model 2

\begin{tabular}{|c|c|c|c|c|c|c|c|c|c|}
\hline \multicolumn{10}{|c|}{ Coefficients $^{\mathrm{a}}$} \\
\hline \multirow[t]{2}{*}{ Model } & \multicolumn{2}{|c|}{$\begin{array}{l}\text { Unstandardized } \\
\text { Coefficients }\end{array}$} & \multirow{2}{*}{$\begin{array}{c}\begin{array}{c}\text { Standardized } \\
\text { Coefficients }\end{array} \\
\text { Beta }\end{array}$} & \multirow[t]{2}{*}{$\mathrm{t}$} & \multirow[t]{2}{*}{ Sig. } & \multicolumn{2}{|c|}{$\begin{array}{c}95,0 \% \\
\text { Confidence } \\
\text { Interval for B }\end{array}$} & Correlations & $\begin{array}{l}\text { Collinearity } \\
\text { Statistics }\end{array}$ \\
\hline & B & $\begin{array}{l}\text { Std. } \\
\text { Error }\end{array}$ & & & & $\begin{array}{l}\text { Lower } \\
\text { Bound }\end{array}$ & $\begin{array}{l}\text { Upper } \\
\text { Bound }\end{array}$ & $\begin{array}{l}\text { Zero- Partial Part } \\
\text { order }\end{array}$ & Tolerance \\
\hline (Constant) & ,094 & ,082 & & 1,138 & ,269 &,- 079 & ,266 & & \\
\hline$1 \longdiv { \mathrm { LY } }$ & ,164 & ,082 & ,418 & 2,004 &, 060 &,- 007 & ,335 & ,418, 418 & $1,000 \quad 1,000$ \\
\hline
\end{tabular}




\section{Pengaruh CSR terhadap Nilai Perusahaan}

Apabila disandingkan dengan profitabilitas akan menghasilkan hasil yang dominan yaitu Corporate Social Responsibility berpengaruh positif signifikan terhadap nilai perusahaan. Jika, Corporate Social Responsibility disandingkan dengan ukuran perusahaan maka pengaruhnya adalah Corporate Social Responsibility berpengaruh negatif signifikan terhadap nilai perusahaan artinya bahwa perusahaan penerapan Corporate Social Responsibility mengambil sedikitnya 0,5\% dari keuntungan yang diperoleh perusahaan farmasi. Sehingga, dapat memajukan program Corporate Social Responsibility dengan baik sesuai dengan operasional perusahaan. perusahaan dapat meningkatkan kepedulian serta kesejahteraan perusahaan di lingkungan perusahaan baik secara eksternal maupun internal yang menyangkut tiga aspek yaitu aspek sosial, aspek ekonomi, serta aspek lingkungan dan membangun citra positif untuk masyarakat bagi perusahaan Hayunta, dkk (2013). Hasil ini sejalan dengan penelitian Susanti et al. (2012); Wulandari (2015); Harjoto dan Laksmana (2016); Humairoh (2017); Marius dan Masri (2017). Dengan begitu CSR berpengaruh positif signifikan terhadap nilai perusahaan. Sehingga, Hipotesis 1 diterima.

\section{Pengaruh Ukuran Perusahaan terhadap Nilai Perusahaan.}

Ukuran perusahaan yang diproksikan dengan logaritma total aset yang dimiliki perusahan farmasi semakin tinggi atau semakin meningkat aset yang dimiliki oleh perusahaan semakin baik dan meningkat pula nilai perusahaan farmasi yang ditunjukkan pada meningkatnya total aset perusahaan dari tahun 2014-2017 pada perusahaan farmasi. Peningkatan ukuran perusahaan berdasarkan aset inilah yang menjadikan perusahaan farmasi mampu berkembang dan tumbuh dengan baik sehingga perlahan akan meningkatkan nilai perusahaan. Sehingga hipotesis 2 diterima dan sejalan dengan penelitian Pratama dan Wiksuana (2016); Meizari dan Oktaviani (2017); Andawasatya, et al. (2017); Hamyat,et al.,(2017); Sofia dan Akhmadi (2018).

\section{Pengaruh Profitabilitas terhadap Nilai Perusahaan}

Profitabilitas bernilai negatif signifikan terhadap nilai perusahaan artinya profitabilitas meningkat maka nilai perusahaan akan cenderung mengalami penurunan. Profitabilitas yang meningkat tidak dibarengi dengan peningkatan harga saham sehingga berimbas pada penurunan nilai perusahaan. Perusahaan berfokus pada teknik orientasi jangka pendek sehingga dapat menurunkan niai perusahaan. Karena jangkauan nilai perusahaan adalah secara menyeluruh yaitu jangka panjang. Sehingaa hipotesis ketiga dalam penelitian ini ditolak. Hal ini didukung oleh penelitian Herawati (2013); Ananda,dkk (2016); serta Thaib dan Dewantoro (2017).

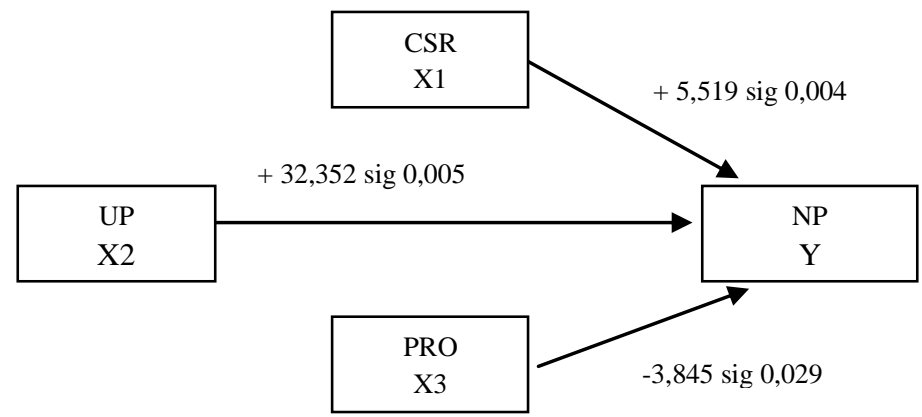

Gambar 1.

Pengaruh Corporate Social Responsibility (CSR), Ukuran perusahaan dan Profitabilitas secara parsial terhadap Nilai Perusahaan

\section{Ukuran Perusahaan memoderasi hubungan CSR terhadap Nilai Perusahaan}

Ukuran perusahaan tidak dapat memoderasi hubungan CSR terhadap Nilai perusahaan disebabkan karena perusahaan farmasi telah mengalokasikan dananya sendiri khusus untuk mendanai Corporate Social Responsibility baik itu ukuran perusahaan yang kecil maupun besar. Selain itu, indikator pengukuran Corporate Social Responsibility dengan menggunakan GRI 4 tidak memiliki batasan-batasan yang dilihat dari ukuran perusahaan baik besar atau kecil sehingga untuk menerapkan luasnya pengungkapan Corporate Social Responsibility pada perusahaan farmasi yang berukuran besar dan kecil dengan citra baik di mata investor tidak menjadi fokus utama dalam penilaian perusahaan sehingga tidak dapat mempengaruhi nilai perusahaan. Maka, hipotesis keempat ditolak. Hal ini tidak sejalan dengan penelitian Putri, dkk. (2016); Puspaningrum (2017); Kiptoo et al. (2017); Waluyo (2017); Jekwam dan Hermuningsih (2018). Namun hasil ini didukung oleh Jiaying-Li (2016); Humairoh (2017); Sari, dkk (2018) serta Karundeng, dkk (2018).. 


\section{Profitabilitas memoderasi hubungan CSR terhadap Nilai Perusahaan}

Profitabilitas tidak dapat memoderasi hubungan Corporate Social Responsibility dengan nilai perusahaan karena profitabilitas suatu perusahaan dalam menerapkan Corporate Social Responsibility mempengaruhi hubungan yang tidak kuat terhadap nilai perusahaan. Perusahaan farmasi masih tergolong perusahaan ekonomis yang menurut Suharto (2009) dalam Wahyuni (2018) perusahaan ekonomis merupakan perusahaan yang memiliki profitabilitas tinggi namun anggaran untuk Corporate Social Responsibility masih rendah. Dilihat dari segi perolehan aset perusahaan sudah dapat dikatakan baik, karena harta yang dimiliki mampu ditingkatkan. Tetapi meningkatnya harta juga tidak menjamin laba mengalami peningkatan karena apabila terjadi perputaran dari harta mengalami peningkatan tetapi tidak dibarengi peningkatan harga saham. Hasil ini tidak sejaan dengan penelitian Ekatah et al..(2011); Wulandari (2015); Nawaiseh et al. (2015); Humairoh (2017); Karundeng,dkk. (2018). Sehingga hasil ini menolak hipotesis kelima.

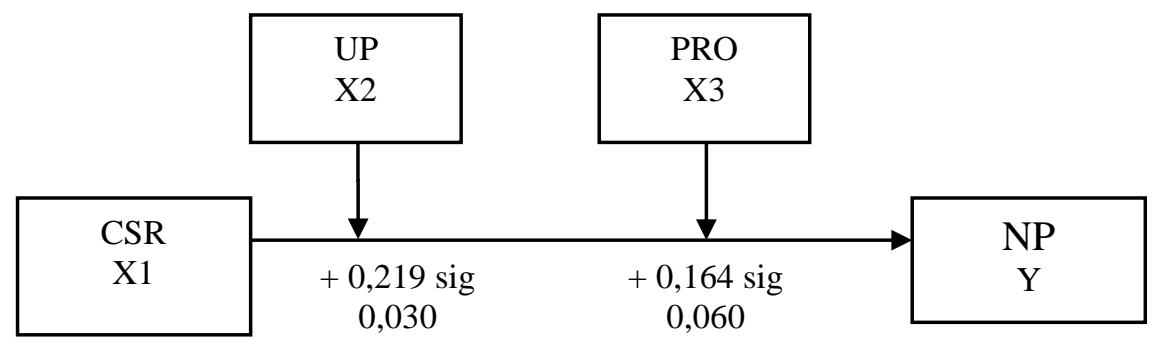

Gambar 2.

Ukuran Perusahaan dan Profitabilitas tidak dapat memoderasi hubungan antara Corporate Social Responsibility (CSR) dan Nilai Perusahaan

\section{PENUTUP}

\section{Simpulan}

1. Corporate Social Responsibility berpengaruh positif signifikan terhadap nilai perusahaan pada perusahaan farmasi yang terdaftar di Bursa Efek Indonesia tahun 2014-2017.

2. Ukuran perusahaan berpengaruh positif signifikan terhadap nilai perusahaan pada perusahaan farmasi yang terdaftar di Bursa Efek Indonesia tahun 2014-2017.

3. Profitabilitas berpengaruh negatif signifikan terhadap nilai perusahaan pada perusahaan farmasi yang terdaftar di Bursa Efek Indonesia tahun 2014-2017.

4. Ukuran perusahaan tidak mampu memoderasi hubungan antara Corporate Social Responsibility (CSR) dan nilai perusahaan pada perusahaan farmasi yang terdaftar di Bursa Efek Indonesia tahun 2014-2017.

5. Profitabilitas tidak mampu memoderasi hubungan antara Corporate Social Responsibility (CSR) dan nilai perusahaan pada perusahaan farmasi yang terdaftar di Bursa Efek Indonesia tahun 2014-2017.

\section{Saran}

1. Perlu diperhatikan Corporate Social Responsibility, ukuran perusahaan dan profitabilitas dalam memulai dan mengembangkan perusahaan.

2. Ukuran perusahaan dan Profitabilitas tidak mampu memoderasi hubungan antara Corporate Social Responsibility (CSR) dan nilai perusahaan pada perusahaan, sehingga perlu dicari solusi atau langkah lain dalam memoderasi CSR dan nilai perusahaan.

\section{DAFTAR PUSTAKA}

Andawasatya, R.R., Indrawati, N.K. and Aisjah, S., (2017). The effect of growth opportunity, profitability, firm size to firm value through capital structure study at manufacturing companies listed on the Indonesian Stock Exchange. Imperial Journal of Interdisciplinary Research, 3(2), pp.1887-1895.

Ananda, Nova Adhitya., Hermanto.,Nugraha AP,I Nyoman. (2016). Pengaruh Profitabilitas, Growth Opportunity Terhadap Nilai Perusahaan dengan Struktur Modal sebagai Variabel Intervening Pada Perusahaan Property, Real Estate \& Building Construction di BEI Periode 2011 - 2014. Jurnal Magister Manajemen Universitas Mataram Vol. 5 No. 4. 
Ardianto, E., Machfudz, D.M., Umar, S. and Toruan, R.L. (2011). Efek kedermawanan pebisnis dan CSR berlipat-lipat. Elex Media Komputindo.

Denziana, Angrita.,Monica,Winda. (2016). Analisa Ukuran Perusahaan dan Profitabilitas terhadap Nilai Perusahaan (Studi Empiris pada Perusahaan yang tergolong LQ45 di BEI Periode 2011-2014). Jurnal Akuntansi \& Keuangan, Vol. 7. Halaman 241-254.Universitas Bandar Lampung.

Dharmanegara, I.B.A., Sitiari, N.W. and Wirayudha, I.D.G.N. (2016). Job Competency and Work Environment: the effect on Job Satisfaction and Job Performance among SME's Worker. IOSR Journal of Journal of Business and Management (IOSRJBM) Volume, 18, pp.19-26.pwngutipan populasi target dan sampe akses.

Ekatah, Innocent., Samy, Martin., Bampton., Roberta., Haabi., Abdel. (2011). The Relationship Between Corporate Social Responsibility and Profitability: The Case of Royal Dutch Shell Plc. Corporate Reputation Review.Volume 14 Number 4.

Goh, T.S. and Simanjuntak, A., (2018). The Influence of Firm Size, Export Ratio and Earning Variablity On Firm Value with Economic Exposure as Intervening Variable in The Manufacturing Industry Sector. Advances in Economics, Business and Management Research (AEBMR), volume 46. 1st Economics and Business International Conference 2017 (EBIC 2017).

Hamyat, H., Sarita, B. and Hasbudin, S., (2017). The Effect of Firm Size and Diversification on Capital Structure and Firm Value (Study in Manufacturing Sector in Indonesia Stock Exchange). The International Journal of Engineering and Science (IJES). ISSN (e), pp.2319-1813.

Herawati, T., (2013). Pengaruh kebijakan dividen, kebijakan hutang dan profitabilitas terhadap nilai perusahaan. Jurnal Manajemen, 2(02), pp.1-18.

Humairoh, Fitri. (2017). Pengaruh Corporate Social Responsibility dan Kepemilikan Manajerial terhadap Nilai Perusahaan dengan Profitabilitas dan Ukuran Perusahaan Sebagai Variabel Moderating pada Perusahaan Manufaktur yang terdaftar di Bursa Efek Indonesia periode 2013-2015. Jurnal Balance, 15(2),162-188. Universitas Katolik Indonesia Atma Jaya.

Jekwam, J.J. and Hermuningsih, S., (2018). Peran Ukuran Perusahaan (Size) Dalam Memoderasi Corporate Social Responsibility Dan Likuiditas Terhadap Kinerja Keuangan Pada Perusahaan Pertambangan Yang Terdaftar Di BEI. Jurnal Magister Manajemen Upajiwa Dewantara, 2(1), pp.76-85.

Karundeng, Frandy.,Nangoi,Grace B., Karamoy,Herman. (2018).“Analisis Pengaruh Corporate Social Responsibility terhadap Nilai Perusahaan dengan Profitabilitas, Kepemilikan Manajerial, dan Ukuran Perusahaan sebagai Variabel Moderasi (Studi Empiris pada Perusahaan Pertambangan yang Terdaftar di Bursa Efek Indonesia Tahun 2012-2016". Jurnal Program Magister Akuntansi.Universitas Sam Ratulangi.

Kiptoo, N.W., Soi, N. and Chepsergon, A. (2017). Effect Of Firm Size And Board Gender On Corporate Social Responsibility Investment Of Firms Listed In Nairobi Security Exchange In Kenya. International Journal of Economics, Commerce and Management United Kingdom.Vol. V, Issue 11, November 2017.

Li-Ju Chen., Shun-Yu Chen. (2011). The influence of profitability on firm value with capital structure as the mediator and firm size and industry as moderators. Investment Management and Financial Innovations, Volume 8, Issue 3, 2011.

Meizari, Ari., Okta Viani,Tri. (2017). "Pengaruh Profitabilitas,Size dan Kebijakan Hutangterhadap Nilai Perusahaan pada Perusahaan Bisnis-27 yang terdaftar di Bursa Efek Indonesia".Jurnal Manajemen Magister, Vol 03.No.02.Juli 2017.Institut Informatika dan Bisnis Darmajaya.

Nawaiseh, Mohammad Ebrahim., Also boa, Soliman. S., Zaid, Rezk Abou, El-shohnah, Youssef. (2015). "Influence of Firm Size and Profitability on Corporate Social Responsibility Disclosures by Banking Firms (CSRD): Evidence from Jordan". Journal of Applied Finance \& Banking, vol. 5, no. 6, 2015, 97111.

Nugroho, Wahyudi Asto. (2012). Pengaruh Profitabilitas, Likuiditas, Dan Leverage Terhadap Nilai Perusahaan (Studi Pada Perusahaan Sektor Manufaktur Di Bursa Efek Indonesia Periode 2008-2011). Artikel Program Studi Magister Manajemen Pascasarjana Universitas Muhammadiyah Surakarta.

Puspaningrum, Yustisia. (2017). Pengaruh Corporate Social Responsibility dan Kepemilikan Manajerial terhadap Nilai Perusahaan dengan Profitabilitas dan Ukuran Perusahaan sebagai Variabel Moderating (Studi Empiris pada Perusahaan Pertambangan di Bursa Efek Indonesia). Jurnal Profita Edisi 2 Universitas Negeri Yogyakarta.

Putra, Cokorda Gde Bayu. (2013). Pengaruh Corporate Governance pada Hubungan Antara Corporate Social Responsibility dengan Price To Book Value pada Perusahaan perbankan yang terdaftar di Bursa Efek Indonesia. Tesis Magister Akuntansi Program Pascasarjana Universitas Udayana. 
Putri, Ayu Kemala., Sudarma, Made., Purnomosidhi, Bambang. (2016). Pengaruh Corporate Social Responsibility terhadap Nilai Perusahaan dengan Ukuran Perusahaan dan Jumlah Dewan Komisaris sebagai Variabel pemoderasi (Studi pada Perusahaan Manufaktur yang Terdaftar Bursa Efek Indonesia. Jurnal Aplikasi Manajemen. Universitas Brawijaya Malang.

Pratama, I Gusti Bagus Angga., Wiksuana, I Gusti Bagus. (2016). Pengaruh Ukuran Perusahaan dan Leverage terhadap Nilai Perusahaan Dengan Profitabilitas Sebagai Variabel Mediasi. E-Jurnal Manajemen Unud, Vol. 5, No. 2, 2016: 1338-1367.

Rumajar, Debora Ully Natalia. (2018). Pengaruh Pengungkapan Corporate Social Responsibility (CSR) terhadap Nilai Perusahaan dengan Ukuran Perusahaan sebagai Variabel Moderasi (Studi empiris pada Perusahaan Perkebunan yang terdaftar di BEI Periode 2015-2016). JOM FEB. Volume 1Edisi1. UniversitasRiau.

Sari, Rafika., Wahyudi, Tertiarto dan Isnurhadi. (2018). Pengaruh Pengungkapan Corporate Social Responsibility dan Jumlah Komite Audit terhadap Nilai Perusahaan Dengan Ukuran Perusahaan Sebagai Variabel Moderator Di Bursa Efek Indonesia. Jurnal Muara Ilmu Ekonomi dan Bisnis. Magister Ilmu Ekonomi. Universitas Sriwijaya. ISSN 2579-6224 (Versi Cetak) Vol. 2, No. 1, April 2018: hlm 210 -217 ISSN-L 2579-6232 (Versi Elektronik).

Sofia, Euis Nurus., Akhmadi. (2018). Pengaruh Profitabilitas dan Ukuran Perusahaan terhadap Nilai Perusahaan dengan Kebijakan Hutang sebagai Variabel Intervening. Jurnal Tirtayasa Ekonomi. Vol.13, No.1, April 2018. Universitas Sultan Ageng Tirtayasa.

Sucuahi, W. and Cambarihan, J.M., (2016). Influence of profitability to the firm value of diversified companies in the Philippines. Accounting and Finance Research, 5(2), p.149.

Susanti, Feby., Marietsa, Fenny., Indriani Rini. (2012). The Influence of Corporate Social Responsibility to Firm Value with Profitability and Leverage as a Moderating Variable. Journal Malaysia Indonesia Conference on Economic, Management and Accounting (MIICEMA). Bengkulu University.

Thaib, I. and Dewantoro, A. (2017). Pengaruh Profitabilitas dan Likuiditas Terhadap Nilai Perusahaan dengan Struktur Modal sebagai Variabel Intervening. Jurnal Riset Perbankan Manajemen dan Akuntansi, 1(1), pp.25-44.

Ghozali, Imam. (2016). Edisi 8. Aplikasi Analisis Multivariete Dengan Program IBM SPSS 23. Badan Penerbit Universitas Diponegoro . Semarang.

Wahyuni, S.F. (2018). Pengaruh Corporate Social Responsibility Terhadap Nilai Perusahaan. Maneggio: Jurnal Ilmiah Magister Manajemen Universitas Muhammadiyah Sumatera Utara.homepage:Vol 1, No. 1, September 2018, 109-117.

Waluyo, W., (2017). Firm Size, Firm Age, and Firm Growth on Corporate Social Responsibility in Indonesia: The Case of Real Estate Companies. European Research Studies, 20(4A), pp.360-369.

Widokarti, J.R., (2014). Masalah Dasar Pengelolaan Corporate Social Responsibility (CSR) Di Indonesia. Jurnal Ilmiah Universitas Terbuka.

Wulandari. Agusta Amanda. (2015.) Dampak Moderasi Profitabilitas terhadap Pengaruh Corporate Social Responsibility pada Nilai Perusahaan Manufaktur yang terdaftar di Bursa Efek Indonesia. Tesis Magister Akuntansi Program Pascasarjana Universitas Udayana.

www.idx.co.id

www.globalreporting.org 